\title{
Canva and Screencast-0-Matic Workshop for Classroom Purpose: A Community Service for Madrasah Ibtidaiyah Teachers
}

\author{
Elis Homsini Maolida ${ }^{*}$, Vina Aini Salsabila ${ }^{2}$ \\ 1,2 Fakultas Keguruan dan Ilmu Pendidikan (FKIP), Universitas Suryakancana, Jl. Pasir Gede Raya \\ 43216, Bojongherang, Cianjur, Provinsi Jawa Barat, Indonesia \\ Corresponding Email: elishomsini@unsur.ac.id ${ }^{1}$.
}

\author{
Article History: \\ Received: Jul 29th 2021 \\ Revised: Aug 5th 2021 \\ Accepted: Aug 16th 2021 \\ Keywords: Canva; \\ Community Service; \\ Madrasah Ibtidaiyah \\ Teachers; Screencast-O- \\ Matic.
}

Abstract: The pandemic has brought a lot of
changes in education, as an example, distance
learning has been used to facilitate young learners
to learn and at the same time protect them from the
spread of the Covid 19 virus. Distance learning has
required teachers to be more creative in teaching so
the learners can comprehend the teachers'
explanations. Workshop Canva and Screencast-O-
Matic were conducted as a community service to
help teachers provide more creative and interactive
teaching using digital applications as learning
media. It involved Madrasah Ibtidaiyah teachers in
Bandung Barat. In presenting the community
service process and result, descriptive qualitative
was used to look at the process and interpret the
result. As a result of workshop, the teachers were
able to design teaching presentation by using Canva
and make teaching recording. The teachers also
admitted that the workshop helped them improve
their digital literacy and their teaching creativity. 


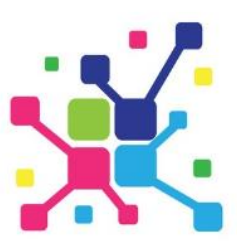

\section{Introduction}

Distance learning is inevitable to maintain the learning process during Covid 19 pandemic. In its implementation, the teachers, whether they are ready or not, are required to find appropriate teaching method, technique and media to make learning process interactive, effective and efficient. However, many teachers are still struggling with the use of technology to support teaching-learning process even though education reformation in ICT has been gauged as an influence of the industrial revolution [1]. This issue needs to be solved by workshops and training so the teachers can adapt to the rapid change of era, this adaptation requirement is termed as "changed or die" [2].

Previously, Siahaan (2015) has identified specific problems faced by the teacher related to their technology literacy, such as unwillingness to make a change in teachinglearning process, teachers' time constraint in preparing technology is in their teaching, limited access to information sources, teacher training on technology use in learning is limited and not equally distributed to all areas as well as multi-interpretation in technical support and rules of technology use for learning [3]. In addition, data revealed by Kementerian Pendidikan dan Kebudayaan RI shows that only 4\% of elementary schools in Indonesia have laboratories and 55\% have libraries [4]. However, those problems cannot be used as a reason of the inability to integrate technology for classroom purposes and for that reason, this community service was conducted.

There have been a lot of applications used by teachers in teaching-learning process such as Padlet, Powtoon, Screencast-0-Matic, Canva, Quizlet, and other applications. Among those apps, Screencast-O-Matic and Canva are the basics to choose to help teacher create effective and interactive teaching-learning media. Screencast-0Matic is a java-based application used to record screens in Windows, Mac and Linux program [5]. In the same paper, it is also explained that Screencast-0-Matic software is a free application that has multifunction to record all monitor activities, even cursor movement. Furthermore, it is easy to use and the teacher can add explanations and comments. This app can be used in Windows 15 XP, Windows Vista and Windows 7 to record webcam activity so tutorials can be recorded and documented and shared via YouTube or blog. The advantages of Screencast 0 Matic as a teaching-learning media motivate many lecturers to initiate trainings of Screencast-0-Matic for teachers $[6,7]$. Meanwhile, Canva as a web-based source provide an application of graphical design, it is the technology of visual media with a drag-and-drop format that provide access to more than a million photos, pictures, graphics and various sizes and types of fonts [8]. Cited in a similar paper, Canva also can be used as a source of visual media and authentic material collection that can be accessed easily. Smaldino et al., (in Yundayani et al, 2019) explain that visual technology can be beneficial to recreate abstract ideas become more concrete, motivate students, focus students' attention, reinform and review materials, also save teacher's energy in the learning process.

Those benefits of Screencast-O-Matic and Canva can be used by Madrasah Ibtidaiyah teachers to improve their teaching quality during the distance learning period (PJJ). It is expected that by the improved practice, the young learners can better comprehend the topics. Besides, this workshop and training are also hoped to facilitate the teachers to compete in industrial revolution $4.0[9,10]$. In line with the issues faced 


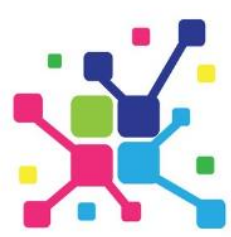

A J A D

Jurnal Pengabdian kepada Masyarakat

Vol. 1, No. 2, October, 2021, pp. 54-60

DOI : https://doi.org/10.35870/ajad.v1i2.13

by the teachers, the advantages of screencast o Matic and Canva, and an urgent need to improve the quality of teaching during PJJ, this workshop was initiated and carried out.

\section{Method}

This community service was carried out through four main stages. The stages can be seen in the following figure:

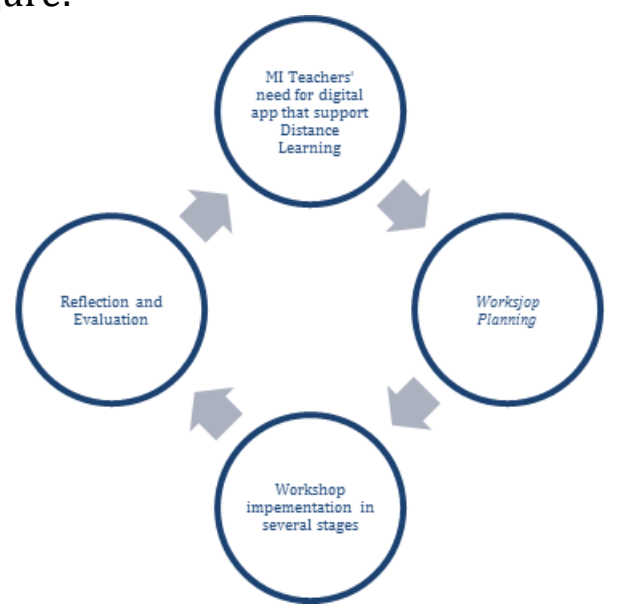

Figure 1. Stages of Canva and Screen O Matic Workshop as a Community Service

There were 4 stages of this community service, started with a need analysis focusing on what the teachers need. The analysis was then put into planning and it was implemented in nine days. To look at the result, a reflection and evaluation were conducted.

a. The implementation of the Workshop

The workshop was conducted in one of private school in West Bandung. It consisted of presentation, practice, and discussion session. The presentation session was carried out to inform teachers, as the participants, regarding the urgency of technology and how to use the technology in teaching activity. Meanwhile, the practice session was an activity which the teachers started to use the applications and were guided to try each feature and made a product. The last session was discussion. This session included question and answer session where the teachers were given opportunities to pose questions and to share their ideas or opinion dealing with the apps or the workshop.

b. Time and duration

This community service activities (from need analysis, planning, and implementation) were carried out from July 12 to July 20, 2020.

c. Location

The workshop took place at Madrasah Ibtidaiyah An-nur, West Bandung. 


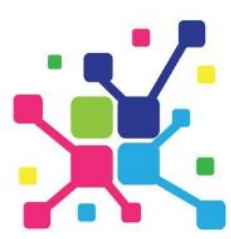

\section{Result and Discussion}

This part elaborates the result and discuss the Canva and Screencast-O-Matic workshop as a community service for teachers.

\section{Workshop Planning}

Before implementing the workshop, the discussion was conducted in order to know the need of MI teachers regarding the use of the digital applications. This discussion involved the lecturers as the implementers and the headmaster as the representative of the school. The result of the discussion showed that most of the teachers need a various digital applications to teach, especially in the context of pandemic. This raised ideas to promote technology in teaching-learning process.

After having a discussion with the headmaster, the implementers started to write the planning of the workshop agenda. It was written in the form of a proposal of service activity. The proposal included the decision of the place and time of the agenda, a rundown of the agenda, list of applications to be presented, and the members of the implementers.

\section{Workshop Implementation}

The implementation was started with a presentation from the first presenter regarding the urgency of technology usage of education. This section aimed to give teachers motivation to keep learning, especially for learning technology in educational sector. This section also gave brief explanation about the advantages of technology and the simulation of the technology usage.

After giving presentation about the urgency of technology, the teachers were asked to discuss the application or instructional technology that they had used during online learning. According to that discussion, it was found that several teachers had been familiar with the use of various technologies. They had utilized social media, messaging app, and other applications. This made the instructors tent to be easy to teach them the use of Canva and Screencast O' Matic.

Then, the next presentation was about the use of Canva in education. This session was started by the simulation of the use of Canva design application. It was shown through the video and the presenters' description. The presenter described the features and functions of Canva design application. Before letting the teachers get familiar with the features of the application, the presenter and team encouraged teachers to sign in the application. After being successful to sign in, the presenter continued to show each feature and function of Canva design and asked the teachers to click and try the feature immediately. During the process, the teachers were guided to follow the instruction and started to make their own design independently. The process of designing their creation spent a lot of time since most of the teachers needed time to be aware of each feature. 


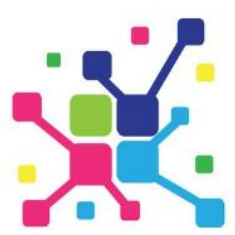

A J A D

Jurnal Pengabdian kepada Masyarakat

Vol. 1, No. 2, October, 2021, pp. 54-60 DOI : https://doi.org/10.35870/ajad.v1i2.13

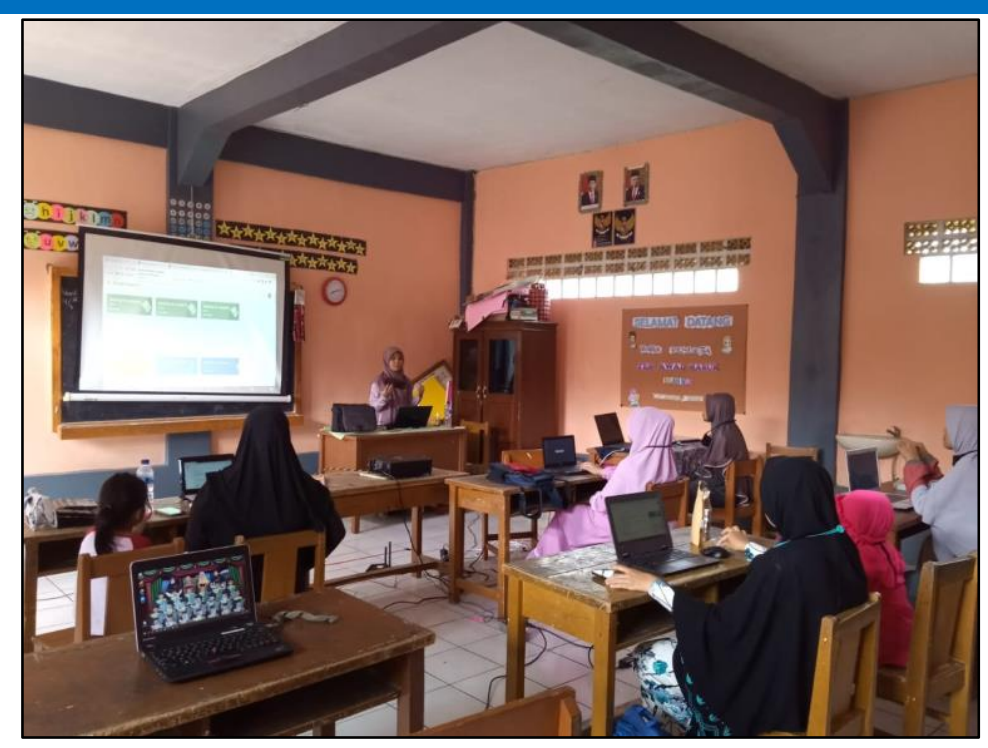

Figure 2. The Implementation of Canva and Screen 0 Matic Workshop as a Community

Service

The last presentation was the use of Screencast-0-Matic. The process conducted in this session was almost similar with the previous session. The presenter firstly introduced the features and the simulation of the utilization of Screencast-0-Matic application. The teachers were then asked to start accessing Screencast-0-Matic website through link given by the presenter. The team made sure that each teacher was able to login the website and able to start recording their explanation. This process was more challenging than the previous session since it deals with teacher's ability to utilize technology and their confidence to record their voice related to their material explanation. During the presentation, the presenter and the teachers were discussing through question-and-answer session, hence the teachers were expected to get deeper understanding and practice of utilizing those applications.

\section{Reflection and Evaluation}

As an evaluation, in both sessions (Canva and Screencast-O-Matic sessions), the teachers were asked to apply the apps to make their teaching media. In this case, all teachers designed at least a teaching presentation by using Canva and made a teaching recording by using Screen O' Matic.
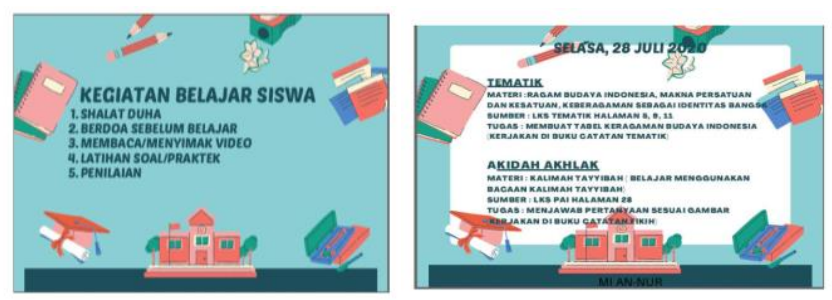

Figure 3. A sample of Participant's Presentation Design Using Canva 
Even though it was not easy and the teachers were in need of guidance, all of them successfully made a presentation and recording. However, the teachers still needed to independently explored and tried the features to create more interactive and interesting presentation design and teaching recording.

The stage of reflection and evaluation also investigated teachers' perspective of the workshop content. In this case, the teachers were asked to give testimony and shared their opinion regarding the workshop. The result of reflection and evaluation revealed that most of the participants were enthusiastic to try new digital application to be implemented in their teaching process. There were also several participants who felt challenged to immediately practice the application because of the urgency of using those apps. They further said that the workshop helped them improve their digital literacy. Moreover, several participants mentioned that this workshop helped them develop their creativity since Canva and Screencast-O-Matic are tools that required the users' creativity to get the best result.

\section{Conclusion}

This workshop is essential to give teachers opportunities to get familiar with various types of digital learning application. Through the workshop, the teachers also had practical experience regarding the utilization of the digital learning application of Canva and Screencast-O-Matic as well as an opportunity to share their knowledge and experience. As a result, all participating teachers are able to design a teaching presentation using Canva and a teaching recording using Screen 0' Matic. It was also admitted that the use of Canva and Screencast-0-Matic help teachers develop their creativity in creating teachers' learning material because the applications provide various features that ease teachers design the learning materials.

\section{Acknowledgements}

We would like to express our gratitude to FKIP Universitas Suryakancana for supporting this community service. We would also express our appreciation for teachers in Madrasah Ibtidaiyah An-Nuur for actively engaged in the program.

\section{References}

[1] Rosa, J.D., 2016. Experiences, perceptions and attitudes on ICT integration: A case study among novice and experienced language teachers in the Philippines. International Journal of Education and Development using ICT, 12(3).

[2] Kasali, R., 2018. The great shifting. Gramedia Pustaka Utama. 


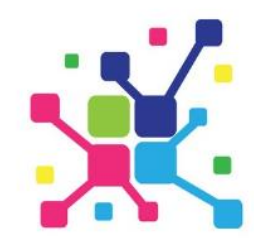

A J A D

Jurnal Pengabdian kepada Masyarakat

Vol. 1, No. 2, October, 2021, pp. 54-60

DOI : https://doi.org/10.35870/ajad.v1i2.13

[3] Siahaan, S., 2015. Pemanfaatan Teknologi Informasi dan Komunikasi dalam Pembelajaran: Peluang, Tantangan, Dan Harapan. Jurnal Teknodik, 19(3), pp.321332.

[4] Tim Dapodikbud Jendela Pendidikan dan Kebudayaan. 2017. Persentase Guru Kualifikasi (Minimal S1). Retrieved September 29, 2017, from http://jendela.data.kemdikbud.go.id/je ndela/\#

[5] Hasanudin, C. and Fitrianingsih, A., 2018. The Implementation of Flipped Classroom using Screencast-O-Matic to Improve Studentsâ $€^{\mathrm{TM}}$ Verbal Linguistic Intelligence. International Journal of Engineering \& Technology, 7(4.15), pp.435439.

[6] Mursyida, L., Dewi, I.P., Lusiana, M. and Marta, R., 2019. Peningkatan Kemampuan Guru Sd Lubuk Alung Dalam Merancang Media Pembelajaran Audio Visual Melalui Aplikasi Camtasia dan Screen O Matic Bagi Guru-Guru Sd 0i Dan Sd 11 Kecamatan Lubuk Alung, Kabupaten Pariaman. Journal of Community Service, 1(1), pp.113118.

[7] Nubatonis, O.E., 2021. Pelatihan Pembuatan Video Pembelajaran Dengan Aplikasi Bandicam dan Screencast O-Matic. Jurnal Nasional Pengabdian Masyarakat, 2(1).

[8] Yundayani, A., Susilawati, S. and Chairunnisa, C., 2019. Investigating The Effect of Canva On Students'writing Skills. English Review: Journal of English Education, 7(2), pp.169-176.

[9] As'ari, A.R., 2014, April. Ideas for developing critical thinking at primary school level. In International Seminar on Addressing Higher Order Thinking: University of Muhammadiyah Makasar.

[10] Jumali, J., 2014. Profesionalisme Guru-Guru Madrasah Ibtidaiyah Muhammadiyah Ceper (Suatu Tinjauan dari Aspek Tingkat Pendidikan). 